\title{
Optimization of osmotic shock process variables for enhancement of the release of periplasmic interferon- $\alpha 2 b$ from Escherichia coli using response surface method
}

\begin{abstract}
The osmotic shock process for the release of periplasmic recombinant human interferon- $\alpha 2 b$ from Escherichia coli was optimized using response surface method (RSM). The process parameters such as $\mathrm{pH}$, buffer concentration and sucrose concentration in hypertonic solution, cell concentration to hypertonic solution, contact time of cells with hypertonic solution, temperature of hypertonic solution, cell concentration to hypotonic solution, contact time of cells with hypotonic solution and temperature of hypotonic solution were initially screened using Plackett Burman design. Further optimization was carried out using central composite design (one of the design in RSM) for sucrose concentration in hypertonic solution as well as cell concentration to hypertonic and hypotonic solutions. The optimal cell concentration was $0.05 \mathrm{~g} / \mathrm{mL}$ in hypertonic solution and $0.2 \mathrm{~g} / \mathrm{mL}$ in hypotonic solution. The use of hypertonic solution containing $18 \%$ sucrose with a combination of $100 \mathrm{mM}$ Tris and $2.5 \mathrm{mM}$ EDTA buffer ( $\mathrm{pH} 8.0$ and $25^{\circ} \mathrm{C}$ ) and cold water $\left(4^{\circ} \mathrm{C}\right)$ as a hypotonic solution gave the optimum release of interferon- $\alpha 2 b$. Increased product concentration in the final solution resulted from the optimized process would reduce the downstream steps during purification. The concept of reuse of hypertonic solution was also demonstrated.
\end{abstract}

Keyword: Interferon- $\alpha 2 b$, Periplasm, Osmotic shock, Process optimization, Response surface methodology, Escherichia coli 